\section{Time trends in colorectal cancer incidence in four regions of Latin America: 1983-2012}

\author{
Tendências temporais na incidência do câncer \\ colorretal em quatro regiões da América Latina: \\ 1983-2012
}

\author{
Tendencias temporales en la incidencia \\ del cáncer colorrectal en cuatro regiones \\ latinoamericanas: 1983-2012
}

\author{
Thayana Calixto de Carvalho 1 \\ Anne Karin da Mota Borges 2 \\ Rosalina Jorge Koifman 1 \\ Ilce Ferreira da Silva 1
}

\begin{abstract}
This study aimed to assess time trends in colorectal cancer incidence from 1983 to 2012 in Latin America. This was an ecological time-series study whose population consisted of individuals aged 20 years or older diagnosed with colorectal cancer. Data from population-based cancer registries in Cali (Colombia), Costa Rica, Goiânia (Brazil), and Quito (Ecuador), were used for rates estimation, while time trends estimations were proceeded by the Joinpoint Regression Program. The study showed an increase in colorectal cancer incidence in men and women in Cali (2.8\% and 3.2\%, respectively), Costa Rica (3.1\% and $2.1 \%$, respectively), and Quito (2.6\% and $1.2 \%$, respectively), whereas in Goiânia, only women showed an increase in colorectal cancer rates (3.3\%). For colon cancer, we observed an increasing trend in incidence rates in men and women in Cali (3.1\% and 2.9\%, respectively), Costa Rica (3.9\% and $2.8 \%$, respectively), and Quito (2.9\% and $1.8 \%)$. For rectal cancer, we observed an increasing trend in incidence in men and women in Cali $(2.5 \%$ and $2.6 \%$, respectively), Costa Rica (2.2\% and 1\%, respectively), and Goiania (5.5\% and 4.6\%, respectively), while in Quito only men showed an upward trend (2.8\%). The study found increases in colorectal cancer, colon cancer, and rectal cancer in four Latin America regions. This findings reflect lifestyle, such as dietary changes, following the economic opening, and the prevalence variations of colorectal cancer risk factors by sex and between the four studied regions. Finally, the different strategies adopted by regions for colorectal cancer diagnosis and screening seem to influence the observed variation between anatomical sites.
\end{abstract}

Colorectal Cancer; Incidence; Time Series; Latin America

\author{
Correspondence \\ T. C. Carvalho \\ Escola Nacional de Saúde Pública Sergio Arouca, Fundação \\ Oswaldo Cruz. \\ Rua Leopoldo Bulhões 1480, Rio de Janeiro, RJ \\ 21041-210, Brasil. \\ thayanacalixto@gmail.com \\ 1 Escola Nacional de Saúde Pública Sergio Arouca, Fundação \\ Oswaldo Cruz, Rio de Janeiro, Brasil. \\ 2 Instituto Nacional de Câncer José Alencar Gomes da Silva, Rio \\ de Janeiro, Brasil.
}




\section{Introduction}

Along with the third-highest cancer incidence (excluding non-melanoma skin cancer), colorectal cancer is considered a public health problem worldwide, especially in Latin America, ranking as the most common digestive system neoplasm in 2020 1. Distribution varies widely between different regions of the world according to the level of development. Regions with high human development index present the highest incidence rates, varying from 33.6 per 100,000 person-years in Northern Europe to 18.5 per 100,000 person-years in South America, and 10.4 per 100,000 person-years in Central America in 2020 1. However, evidences suggest growing incidence in countries with economic transition 2, alongside stabilization or reduction in developed countries' rates in the last 15 years 3 .

Although several studies have analyzed colorectal cancer incidence worldwide, only a few were carried out in Latin America ${ }^{4}$. Thus, the behavior of this neoplasm incidence in developing countries is not well defined. Some studies performed so far have assessed the trend in incidence rates for only 10 years 4,5 or were conducted 20 years ago 5 , besides not assessing the colon and rectal cancer patterns separately 6 . Arnold et al. ${ }^{2}$ conducted a complete study to date, using the International Agency for Research on Cancer (IARC) data from 1980 to 2007, and found three distributions of colorectal cancer: increasing incidence and mortality rates in recent decades in countries with rapid economic transition, including Brazil, Costa Rica, and Colombia; increasing incidence and decreasing mortality in high Human Development Index (HDI) countries, including Canada and the United Kingdom; and decreases in both rates in countries with very high HDI as Australia, Japan, and France. However, the study did not analyze the rates by anatomical site, nor did it include Ecuador among the studied countries. Also, Arnold et al.'s study focused on socioeconomic differences between developed and developing countries, without considering the political, social, and economic changes within these countries throughout the study period. Thus, we aimed to assess time trends in incidence rates for colorectal cancer in Cali (Colombia), Goiânia (Brazil), Quito (Ecuador), and Costa Rica from 1983 to 2012, according to sex and anatomical site.

\section{Methods}

\section{Study design and population}

We proceeded an ecological time-series study whose population was consisted of individuals aged 20 to 79 years diagnosed with colorectal cancer reported by population-based cancer registries (PBCR) from 1983 to 2012 in Cali $(\mathrm{n}=5,528)$ and Costa Rica ( $=8$,595), and from 1988 to 2012 in Goiânia ( $\mathrm{n}=$ $3,856)$ and Quito $(\mathrm{n}=2,463)$. Colorectal cancer incidence in the age group up to 19 years old is very low 1 , and the majority is genetic-related cancer cases 7,8 . Therefore, we focused on adult individuals $(20+)$, aiming to raise hypotheses regarding the political, social, and economic changes that could have influenced the incidence rates of colorectal cancer.

\section{Data sources}

Cancer Incidence in Five Continents (CI5) series, volumes VI to XI, published by the IARC (https:// ci5.iarc.fr/), were the source of data on the number of colorectal cancer cases in each region, year and age at diagnosis, and size of at-risk populations. Discrepancies on the size of at-risk population in Goiânia between CI5 series and the Brazilian Institute of Geography and Statistics (IBGE) led us to work with the IBGE data for 2003 to 2007.

The CI5 data were obtained from each country or region's PBCR and underwent rigorous quality assessment. Four chosen PBCRs met the criteria of the IARC editorial process, attaining high quality. They were also the only PBCRs in Latin America with at least 20 years of uninterrupted data.

All data provided by the CI5 were coded according to the International Classification of Diseases for Oncology, 3rd edition (ICD-O-3), and converted to the International Classification of Diseases, 10th revision (ICD-10). This process guarantees the use of the same verifications of validity to all data from different regions. 


\section{Data analysis}

For each region, crude incidence rates were calculated for colorectal cancer (C18-21), colon cancer (C18), and rectal cancer (C19-21) by years, and expressed per 100,000 at-risk person-years, stratified by sex. After this procedure, the incidence rates were standardized by age (ASRs) with the truncated method, using the world population as the standard, as proposed by Segi et al. ${ }^{9}$ and modified by Doll et al. 10. Data on colorectal cancer incidence included a proportion of cases with the unknown age bracket. To address such issue, a correction factor was obtained via the product of the sum of the number of reported cases in a given year, including those with unknown age group and the same sum excluding those with the unknown age group 11. Thus, this factor corrected the standardized incidence rates of colorectal, colon, and rectal cancer.

The software Joinpoint Regression Program, version 4.5.0.1 (https://surveillance.cancer.gov/ joinpoint/), was used to calculate the average annual percent change (AAPC) for the entire period and the annual percentage change (APC) for each follow-up and the respective 95\% confidence intervals (95\%CI), using a t-test to determine whether the AAPCs and APCs differed statistically from zero. The adequate log-linear regression models were selected to identify the occurrence of possible inflection points where significant changes in the trends had occurred, allowing a minimum number of joinpoints necessary to adjust the data when the APCs changed significantly. The best model was selected based on the Montecarlo permutation test. Statistical significance was set at $\mathrm{p}<0.05$.

\section{Results}

The study analyzed 20,442 cases of colorectal cancer in four regions of Latin America in the study period, of which 5,528 (27\%) in Cali, 8,595 (42\%) in Costa Rica, 3,856 (19\%) in Goiânia, and 2,463 (12\%) in Quito. Figure 1 shows the time trends for colorectal, colon, and rectal cancer according to sex in the four regions. Among them, Goiânia showed the highest rates of colorectal cancer (32.2/100,000 men, and 28.6/100,000 women), colon cancer (19.3/100,000 men, and 17.5/100,000 women), and rectal cancer (13.0/100,000 men, and 12.7/100,000 women), whereas Quito presented the lowest rates for colorectal cancer (13.9/100,000 men and 14.6/100,000 women), colon cancer (8.6/100,000 men and 8.9/100,000 women), and rectal cancer (5.4/100,000 men and 5.7/100,000 women) (Table 1).

Table 2 shows trends in colorectal cancer, colon cancer, and rectal cancer according to sex in the four regions. The ASRs showed a colorectal cancer increase for both, men and women, in Costa Rica (AAPC = 3.1\%; 95\%CI: 2.7-3.6 and AAPC = 2.1\%; 95\%CI: 1.5-2.8; respectively), Quito (AAPC = 2.6\%; 95\%CI: $1.4-3.9$ and $\mathrm{AAPC}=1.2 \%$; 95\%CI: 0.2-2.3; respectively) and Cali (AAPC = 2.8\%; 95\%CI: 2.0-3.6 and $\mathrm{AAPC}=3.2 \%$; 95\% CI: 1.8-4.6, respectively). In Goiânia, women showed increasing rates throughout the period (AAPC $=3.3 \%$; 95\%CI: 2.1-4.5).

Regarding the colon cancer trends, we observed a constant increase in ASR in men and women in Cali $(\mathrm{AAPC}=3.1 \%$; 95\%CI: 2.2-4.0 and $\mathrm{AAPC}=2.9 \%$; 95\%CI: 2.1-3.8; respectively), Costa Rica (AAPC = 3.9\%; 95\%CI: 3.1-4.7 and AAPC = 2.8\%; 95\%CI: 2.2-3.5; respectively), and Quito (AAPC = 2.9\%; 95\%CI: 1.2-4.6 and AAPC = 1.8\%; 95\%CI: 0.6-3.0; respectively). In Goiânia, men and women showed an increasing trend without statistical significance (Table 2).

Rectal cancer showed an increasing trend in incidence in men in Cali (AAPC $=2.5 \%$; 95\%CI: 1.43.6), Costa Rica (AAPC = 2.2\%; 95\%CI: 1.4-3.0), Goiânia (AAPC = 5.5\%; 95\%CI: 3.8-7.3), and Quito $(\mathrm{AAPC}=2.8 \%$; 95\% CI: 0.7-5.0), whereas for women we observed a significant increase in Cali (AAPC = 2.6\%; 95\%CI: 1.7-3.5), Costa Rica (AAPC = 1.0\%; 95\%CI: 0.0-2.1), and Goiânia (AAPC = 4.6\%; 95\%CI: 2.7-6.6) (Table 2). 
Figure 1

Time trends in incidence rates of colorectal, colon, and rectal cancer standardized by the world population per 100,000 person-years in Cali (Colombia) and Costa Rica from 1983 to 2012 and in Goiânia (Brazil) and Quito (Ecuador) from 1988 to 2012.

1a) Colorectal (males)

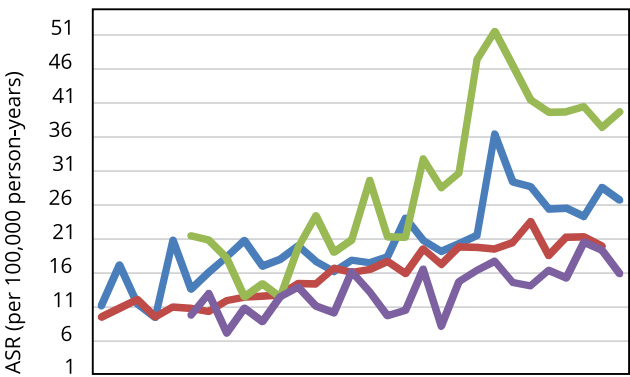

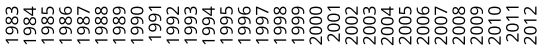

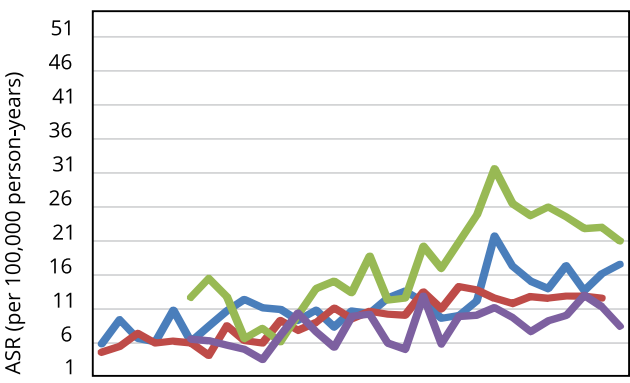

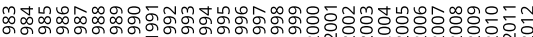

1e) Rectum (males)

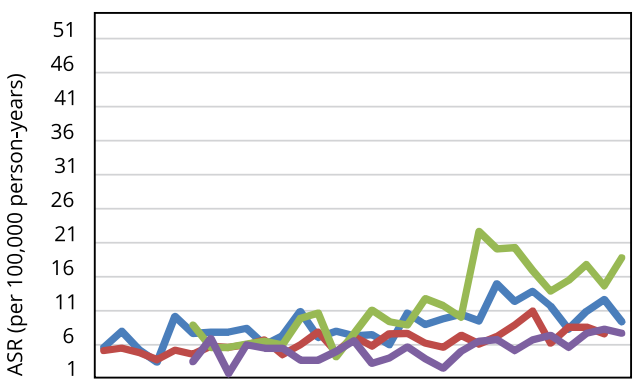

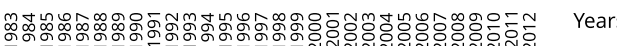

1c) Colon (males)

1b) Colorectal (females)

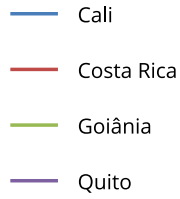

Years

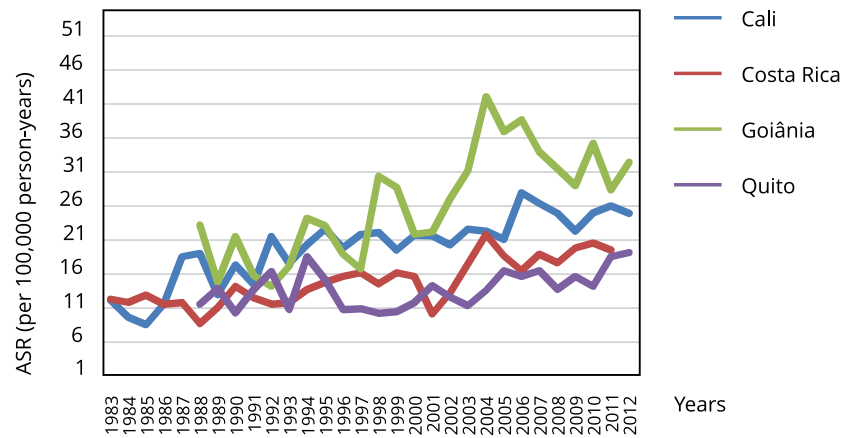

1d) Colon (females)
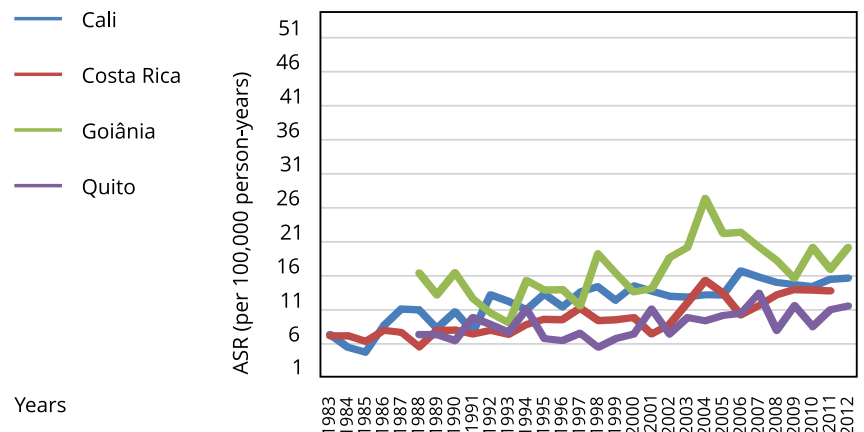

- Cali

Costa Rica

- Goiânia

— Quito

1f) Rectum (females)

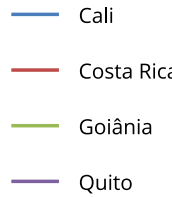

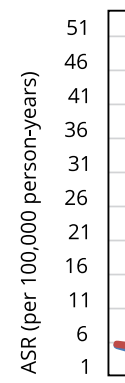

- Cali

Costa Rica

— Goiânia

— Quito

ASR: age-standardized rate. 
Table 1

Age-standardized rate (ASR) and average annual percent change (AAPC) for colorectal, colon, and rectal cancer according to sex in Cali (Colombia) from 1983 to 2012, Costa Rica from 1983 to 2011, and Goiânia (Brazil) and Quito (Ecuador) from 1988 to 2012.

\begin{tabular}{|c|c|c|c|c|c|c|c|c|}
\hline \multirow[t]{2}{*}{ PBCR/Cancer } & \multicolumn{4}{|c|}{ Men } & \multicolumn{4}{|c|}{ Women } \\
\hline & Cases & ASR * & AAPC & $95 \% \mathrm{Cl}$ & Cases & ASR * & AAPC & $95 \% \mathrm{Cl}$ \\
\hline \multicolumn{9}{|l|}{ Colorectal } \\
\hline Cali & 2,448 & 20.03 & $2.8 * \star$ & $2.0-3.6$ & 3,080 & 21.7 & $3.2 \star \star$ & $1.8-4.6$ \\
\hline Costa Rica & 4,249 & 16.9 & $3.1 \star \star$ & 2.7-3.6 & 4,346 & 14.9 & $2.1 \star \star$ & $1.5-2.8$ \\
\hline Goiânia & 1,775 & 32.2 & 2.1 & $-1.4-5.7$ & 2,081 & 28.6 & $3.3 * \star$ & $2.1-4.5$ \\
\hline Quito & 1,088 & 13.9 & $2.6 * \star$ & 1.4-3.9 & 1,375 & 14.6 & $1.2 \star \star$ & $0.2-2.3$ \\
\hline \multicolumn{9}{|l|}{ Colon } \\
\hline Cali & 1,415 & 11.7 & 3.1 ** & $2.2-4.0$ & 1,829 & 12.9 & $2.9 \star \star$ & $2.1-3.8$ \\
\hline Costa Rica & 2,588 & 10.2 & $3.9 * \star$ & $3.1-4.7$ & 2,797 & 9.5 & $2.8 * \star$ & $2.2-3.5$ \\
\hline Goiânia & 1,061 & 19.3 & 1.3 & $-2.7-5.6$ & 1,201 & 17.5 & 2.4 & $-0.4-5.3$ \\
\hline Quito & 671 & 8.6 & $2.9 * \star$ & $1.2-4.6$ & 847 & 8.9 & $1.8 * \star$ & $0.6-3.0$ \\
\hline \multicolumn{9}{|l|}{ Rectal } \\
\hline Cali & 1,033 & 8.6 & $2.5 * \star$ & $1.4-3.6$ & 1,251 & 8.8 & $2.6 \star \star$ & $1.7-3.5$ \\
\hline Costa Rica & 1,659 & 6.6 & $2.2 * \star$ & 1.4-3.0 & 1,549 & 5.3 & $1.0 * *$ & $0.0-2.1$ \\
\hline Goiânia & 713 & 13.0 & $5.5 * \star$ & $3.8-7.3$ & 880 & 12.7 & $4.6 * \star$ & $2.7-6.6$ \\
\hline Quito & 417 & 5.4 & $2.8 * \star$ & $0.7-5.0$ & 528 & 5.7 & 0.8 & $-1.0-2.6$ \\
\hline
\end{tabular}

95\% Cl: 95\% confidence interval; PBCR: population-based cancer registry.

* Expressed in 100,000 person-years and standardized to the world population;

** Statistically significant $(p<0.05)$.

\section{Discussion}

This study found an upward trend in colorectal cancer, colon cancer, and rectal cancer for both sex in Cali, Costa Rica, Goiannia, and Quito during the period assessed. These results are consistent with the increase in colorectal cancer incidence reported in other countries in economic transition, such as Argentina, Chile, China, Czech Republic, and Slovakia 4,12. Although the incidence increased in the four regions of Latin America, it occurred differently between the regions, with Goiânia showing the highest rates, both in men and women (32.2/100,000 men and 28.6/100,000 women). On the other hand, Quito showed the lowest rates (13.9/100,000 men and 14.6/100,000 women). Results also showed differences in the magnitude of the rates by sex. While women in Cali and Quito exhibited higher incidence rates of colorectal cancer, colon cancer, and rectal cancer, in Goiânia and Costa Rica, the highest rates were in men. These findings corroborate with the study by Sierra \& Forman 4 in 13 countries of Central and South America from 1985 to 2007, who found higher incidence rates in men than in women (male/female ratio between 1 and 1.8:1).

The increasing rates seem to reflect pertinent questions of population aging, resulting from the demographic transition over the years in Latin American countries, besides lifestyle changes related to economic opening and monetary stabilization in recent decades. This process led to the expansion of the consumer market and increased exposure to risk factors for this neoplasm 13 . The literature shows that the main risk factors for colorectal cancer are lifestyle issues, especially inadequate diet (diets rich in red and processed meat) 14 and low consumption of fruits and vegetables 15, physical inactivity 16 , obesity 17 , smoking 18 , and alcohol consumption 18 . Thus, differences in the prevalence of these risk factors may have affected the observed variations in the incidence curve slope for this neoplasm in different regions and between the sex.

In Brazil, Mielke et al. ${ }^{19}$ assessed the time trend in physical activity from 2006 to 2012 in the 26 state capitals and the Federal District. The authors used physical activity data in multiple domains 
Table 2

Incidence trends according to anatomical site and sex in Cali (Colombia) from 1983 to 2012, Costa Rica from 1983 to 2011, and Goiânia (Brazil) and Quito (Ecuador) from 1988 to 2012.

\begin{tabular}{|c|c|c|c|c|c|c|c|c|c|c|c|c|}
\hline \multirow[t]{2}{*}{ Anatomical site */PBCR } & \multirow[t]{2}{*}{ Sex } & \multicolumn{3}{|c|}{ Trend 1 ** } & \multicolumn{3}{|c|}{ Trend 2 ** } & \multicolumn{3}{|c|}{ Trend 3 ** } & \multicolumn{2}{|c|}{ Entire period ** } \\
\hline & & Period & APC & $95 \% \mathrm{Cl}$ & Period & APC & $95 \% \mathrm{Cl}$ & Period & APC & $95 \% \mathrm{Cl}$ & AAPC & $95 \% \mathrm{Cl}$ \\
\hline \multicolumn{13}{|l|}{ Colorectal (C18-21) } \\
\hline \multirow[t]{2}{*}{ Cali } & $\mathrm{M}$ & $1983-2012$ & $2.8 * \star \star$ & $2.0-3.6$ & & & & & & & $2.8 * \star \star$ & 2.0-3.6 \\
\hline & $\mathrm{F}$ & 1983-1992 & $7.2 * * *$ & 3.3-11.3 & $1992-2012$ & $1.4 * \star \star$ & $0.3-2.6$ & & & & $3.2 * \star \star$ & $1.8-4.6$ \\
\hline \multirow[t]{2}{*}{ Costa Rica } & $\mathrm{M}$ & $1983-2011$ & $3.1 * \star \star$ & $2.7-3.6$ & & & & & & & $3.1 * \star \star$ & $2.7-3.6$ \\
\hline & $\mathrm{F}$ & 1983-2011 & $2.1 \star \star \star$ & $1.5-2.8$ & & & & & & & $2.1 \star \star \star$ & $1.5-2.8$ \\
\hline \multirow[t]{2}{*}{ Goiânia } & $M$ & 1988-1991 & -17.6 & $-34.9-4.2$ & 1991-2005 & $8.9 * \star \star$ & $6.3-11.6$ & $2005-2012$ & -1.7 & $-7.7-4.7$ & 2.1 & $-1.4-5.7$ \\
\hline & $\mathrm{F}$ & 1988-2012 & $3.3 * \star \star$ & $2.1-4.5$ & & & & & & & $3.3 * \star \star$ & $2.1-4.5$ \\
\hline \multirow[t]{2}{*}{ Quito } & $\mathrm{M}$ & $1988-2012$ & $2.6 * \star \star$ & $1.4-3.9$ & & & & & & & $2.6 \star \star \star$ & 1.4-3.9 \\
\hline & $\mathrm{F}$ & 1988-2012 & $1.2 \star \star \star$ & $0.2-2.3$ & & & & & & & $1.2 \star \star \star$ & $0.2-2.3$ \\
\hline \multicolumn{13}{|l|}{ Colon (C18) } \\
\hline \multirow[t]{2}{*}{ Cali } & M & $1983-2012$ & $3.1 * \star *$ & $2.2-4.0$ & & & & & & & $3.1 * \star \star$ & $2.2-4.0$ \\
\hline & $\mathrm{F}$ & 1983-2012 & $2.9 \star \star \star$ & $2.1-3.8$ & & & & & & & $2.9 \star \star \star$ & $2.1-3.8$ \\
\hline \multirow[t]{2}{*}{ Costa Rica } & M & 1983-2011 & $3.9 * \star \star$ & $3.1-4.7$ & & & & & & & $3.9 * \star \star$ & $3.1-4.7$ \\
\hline & $\mathrm{F}$ & 1983-2011 & $2.8 * \star \star$ & $2.2-3.5$ & & & & & & & $2.8 * \star \star$ & $2.2-3.5$ \\
\hline \multirow[t]{2}{*}{ Goiânia } & M & 1988-1991 & -22.2 & $-41.1-2.6$ & 1991-2005 & $9.5 * \star \star$ & $6.4-12.7$ & $2005-2012$ & -2.8 & $(-9.7-4.6)$ & 1.3 & $-2.7-5.6$ \\
\hline & $\mathrm{F}$ & 1988-2012 & 2.4 & $-0.4-5.3$ & & & & & & & 2.4 & $-0.4-5.3$ \\
\hline \multirow[t]{2}{*}{ Quito } & $M$ & 1988-2012 & $2.9 \star \star \star$ & $1.2-4.6$ & & & & & & & $2.9 \star \star \star$ & $1.2-4.6$ \\
\hline & $\mathrm{F}$ & 1988-2012 & $1.8 * \star \star$ & $0.6-3.0$ & & & & & & & $1.8 * \star \star$ & $0.6-3.0$ \\
\hline \multicolumn{13}{|l|}{ Rectal and anal (C19-21) } \\
\hline \multirow[t]{2}{*}{ Cali } & $M$ & 1983-2012 & $2.5 * \star \star$ & $1.4-3.6$ & & & & & & & $2.5 \star \star \star$ & 1.4-3.6 \\
\hline & $\mathrm{F}$ & 1983-2012 & $2.6 * \star \star$ & $1.7-3.5$ & & & & & & & $2.6 \star \star \star$ & $1.7-3.5$ \\
\hline \multirow[t]{2}{*}{ Costa Rica } & M & $1983-2011$ & $2.2 \star \star \star$ & $1.4-3.0$ & & & & & & & $2.2 \star \star \star$ & $1.4-3.0$ \\
\hline & $\mathrm{F}$ & $1983-2011$ & $1.0 * \star \star$ & $0.0-2.1$ & & & & & & & $1.0 * \star \star$ & $0.0-2.1$ \\
\hline \multirow[t]{2}{*}{ Goiânia } & M & $1988-2012$ & $5.5 * \star \star$ & $3.8-7.3$ & & & & & & & $5.5 * \star \star$ & $3.8-7.3$ \\
\hline & $\mathrm{F}$ & $1988-2012$ & $4.6 * \star \star$ & $2.7-6.6$ & & & & & & & $4.6 \star \star \star$ & $2.7-6.6$ \\
\hline \multirow[t]{2}{*}{ Quito } & M & 1988-2012 & $2.8 * \star \star$ & $0.7-5.0$ & & & & & & & $2.8 * \star \star$ & $0.7-5.0$ \\
\hline & $\mathrm{F}$ & $1988-2012$ & 0.8 & $-1.0-2.6$ & & & & & & & 0.8 & $-1.0-2.6$ \\
\hline
\end{tabular}

95\%Cl: 95\% confidence interval; AAPC: average annual percentage change; APC: annual percentage change; F: females; M: males; PBCR: populationbased cancer registry.

* According to the International Classification of Diseases, 10th revision;

** Joinpoint Regression Program, version 4.5.0.1 (https://surveillance.cancer.gov/joinpoint/);

*** Statistically significant $(p<0.05)$.

(leisure, transportation, occupation, and household) obtained from the Risk and Protective Factors Surveillance System for Chronic Non-Comunicable Diseases Through Telephone Interview (Vigitel). They found that time in physically active commuting decreased from $12.9 \%$, in 2006-2008, to 5.8\%, in 2009-2012, $(\mathrm{p}<0.001)$, with more substantial declines in individuals aged $25-34$ years $(-16.8 \%)$ than in those aged 55-64 years (-1.7\%) 19. Monteiro et al. 20 found a time trend in the relative contribution of ultraprocessed foods in Brazil's metropolitan areas in 1986-1987, 1995-1996, and 2002-2003. In the last three decades, the authors found that consumption of unprocessed and minimally processed foods and processed culinary ingredients has been replaced steadily by consuming ultra-processed foods in both high-income and low-income groups 20. The United Nations reported an increased prevalence of excess weight and obesity in Latin America, varying from 33.3\% and 7.8\% in 1975 to 57.7\% and $23.6 \%$ in 201521 .

Meanwhile, each country's public policies are essential for dealing with the increasing incidence of colorectal cancer 22 . Identified effective measures for reducing the prevalence of risk factors for this 
neoplasm are inter-sector approaches, mainly primary prevention such as strengthening food systems that simultaneously promote prosperity, equity, environmental sustainability, and health 23 . Latin America has witnessed experiences such as taxation of soda drinks in Mexico 24, new labeling with nutritional traffic lights in Ecuador 25, and the publication of food guides adopting foods classification based on their processing level in Brazil 26 and Uruguay 27. However, most commitments assumed by public management were not translated into real measures 23 . Such reality is evident because the prevalent Brazilian dietary pattern includes high consumption of red and processed meats, oils and fats, and ultra-processed foods 20 .

Besides promoting the change of dietary habits as a public health program, primary prevention efforts should include promoting physical activity, which is a preventive factor for obesity and, therefore, a preventive factor for colorectal cancer 17,18,28. According to Continuous Update Project (CUP) data from World Cancer Research Fund (WCRF) 29, there is strong evidence that being physically active decreases colon cancer risk. Physical activity reduces body fatness and, therefore, has a beneficial effect on colorectal cancer risk, possibly reducing insulin resistance and inflammatory processes $17,18,29$. Other mechanisms by which physical activity may reduce colorectal cancer risk include stimulating digestion and reducing transit time through the intestine 16,29 .

Regional differences in patterns of increasing incidence of colorectal cancer can also be affected by the number of screenings for this neoplasm 30 . Screening programs for colorectal cancer are essential measures to assess the global burden of colorectal cancer 12. Screening may lead to a shortterm increase in incidences of colorectal cancer, through higher detection of prevalent cases, besides reducing the long-term incidence of the disease by removing premalignant lesions 12 . Thus, differences in the implementation of screening programs for this neoplasm may explain the variation in colorectal cancer incidence in these regions, for example Costa Rica has no national guidelines recommending colorectal cancer screening 30.

Whereas the Brazilian Ministry of Health has recommended, since 2002, that individuals aged over 50 years should have an annual fecal occult blood test. If the result is positive, the recommendations include a colonoscopy or rectosigmoidoscopy 31 . The opportunistic screening model is currently in operation in the majority of the country 32 . However, it is necessary to consider regional differences in Brazil when action planning, with a focus on cancer care, considering decentralizing these actions to ensure their effectiveness 33,34 .

According to the anatomical site, the analysis showed a significant increase of AAPC for rectal and anal cancer in Goiânia (5.5\% for men and $4.6 \%$ for women), whereas, in the other regions, the increase was around $2.5 \%$. These results suggest that the increased incidence of colorectal cancer in Goiânia correlates with the increasing rectal cancer incidence, since a remarkable rectal cancer increase was highlighted in men from 1991 to 2005 (6.4\% to 12.7\%), followed by a non-significant decrease $(-2.8 \%)$ from 2005 to 2012. Among women, the increase was smaller (2.4\%), but constant. Malignant neoplasms of the colon and rectum/anus have distinct etiologies 35 , and the differences in both the prevalence of risk factors and screening and diagnostic strategies could influence the slope in the incidence curve in different anatomic sites 35 .

The HPV infection is a significant risk factor for rectal and anal cancer development 36 . The Brazilian Ministry of Health, in partnership with the Moinho de Ventos Hospital used a cross-sectional study, called POP-Brasil, to assess the prevalence of HPV (types, 6, 11, 16, and 18) in 26 state capitals and the Federal District in 2016 37. The study included 5,812 sexually active women and 1,774 sexually active men aged 16 to 25 years, and estimated HPV prevalence using genital and oral samples with DNA extraction, followed by genotyping based on PCR amplification and hybridization. The estimated overall HPV prevalence in Brazil was 54.6\%, and HPV types 16 and 18 - with a high risk of epithelial cancer - were present in $38.4 \%$ of the population ${ }^{37}$. In Goiânia, the estimated HPV prevalence was $54.1 \%$, with $35.1 \%$ presenting high-risk HPV 37 . Evidence in the literature suggests that countries with high HPV prevalence have a higher incidence of neoplasms related to this infection 38 . Another possible explanation for differences observed between the sexes is that the implementation of cervical cancer screening programs in Brazil 36 since 1998 may have contributed to the increase in the diagnosis of rectal cancer in women, as the female perineal area was frequently examined by health professionals 39 . 
The different screening and diagnostic strategies adopted in each region may also explain the observed variations according to anatomical site. Neoplasms of the colon and rectum have distinct characteristics and require different screening methods and diagnosing lesions 40. For example, flexible sigmoidoscopy is limited to diagnosing rectal or distal colon cancer, since it does not allow visualizing most of the colon during the examination 41,42. Thus, methods of fecal occult blood testing, digital rectal examination, and flexible sigmoidoscopy are targeted to diagnosing rectal cancer, whereas for diagnosis of colon cancer, the recommendations include colonoscopy 41,42.

The first limitation of this study was the data from PBCRs, which have inherent secondary data problems. Nevertheless, the use of PBCR data that are considered high-quality by the IARC allowed generating information that adds knowledge to the field, raising hypotheses on the potential factors that could lead to increased incidence of colorectal cancer in Latin American countries. Notably, the inclusion in this study of Cali, Costa Rica, Goiânia, and Quito only implies that the findings are not necessarily representative of Latin America as a whole. However, the PBCRs in these regions are high quality according to the IARC criteria, lending credibility to the data accuracy. Although we had found discrepancies in the population of Goiânia, IBGE data corrected this information, by population reference.

Although the rectosigmoid junction miss-classification may limit disaggregated analysis by primary colon sites, the frequency of neoplasms at the rectosigmoid junction is small (2.9\%) 43 . Thus, miss-classification in such a cancer site would poorly influence the estimates. Besides, colon and rectum tumors have distinct etiologies, that can be influenced by social, lifestyle (diet, physical inactivity, so on), political, and economic aspects 3,13,29. For example, the practice of physical activity, that plays a protective role in colon cancer, but not in rectal cancer ${ }^{29}$. Furthermore, this limitation is minimized by the fact that we also presented data on colorectal cancer.

Meanwhile, this study displayed essential advantages. As far as we know, this study was the first to assess time trends in colorectal cancer according to sex and anatomical sites in different regions of Latin America. Our study also assessed the evolution in the incidence rates of colorectal cancer up to 2012, the most recent period in the data published by the IARC, considering the political, social, and economic changes in these countries throughout the period.

The study found increases in colorectal cancer, colon cancer, and rectal cancer in four LatinAmerica regions, especially rectal cancer in Goiânia. The findings reflect lifestyle, such as dietary changes, following 1980s economic opening in Costa Rica, and the early 1990s in Brazil, Colombia, and Ecuador, and the prevalence variations of colorectal cancer risk factors by sex and between the four studied regions. Finally, the different strategies adopted by regions for colorectal cancer diagnosis and screening seem to influence the observed variation between anatomical sites.

This study findings suggest the need for specific measures to control the risk factors associated with colorectal cancer, besides effective screening and control programs for these neoplasms in the four countries. These measures can contribute to colorectal cancer incidence control, especially among men and women in Goiânia. 


\section{Contributors}

T. C. Carvalho contributed to the acquisition, analysis and interpretation of data and wrote the first draft of the manuscript. A. K. M. Borges and I. F. Silva made substantial contributions to the conception and design of the work, and guided all the analyses of the study. R. J. Koifman critically reviewed the study. All authors approved the final version of the manuscript.

\section{References}

1. International Agency for Research on Cancer. Cancer today. http://gco.iarc.fr/today/home (accessed on 20/Jan/2021).

2. Arnold M, Sierra MS, Laversanne M, Soerjomataram I, Jemal A, Bray F. Global patterns and trends in colorectal cancer incidence and mortality. Gut 2017; 66:683-91.

3. Tsoi KKF, Hirai HW, Chan FCH, Griffiths S, Sung JJY. Predicted increases in incidence of colorectal cancer in developed and developing regions, in association with ageing populations. Clin Gastroenterol Hepatol 2017; 1:892900.e4.

4. Sierra MS, Forman D. Burden of colorectal cancer in Central and South America. Cancer Epidemiol 2016; 44 Suppl 1:S74-81.

5. Reis RS, Santos MO, Bloch KV. Colorectal cancer in Porto Alegre and Fortaleza, Brazil: incidence trends and distribution pattern from 1990 to 1999. Cad Saúde Pública 2009; 25:1046-53.

6. Torre LA, Siegel RL, Ward EM, Jemal A. Global cancer incidence and mortality rates and trends: an update. Cancer Epidemiol Biomarkers Prev 2016; 25:16-27.

7. Mork ME, You YN, Ying J, Bannon SA, Lynch PM, Rodriguez-Bigas MA, et al. High prevalence of hereditary cancer syndromes in adolescents and young adults with colorectal cancer. J Clin Oncol 2015; 33: 3544-9.

8. You YN, Lee LD, Deschner BW, Shibata D. Colorectal cancer in the adolescent and young adult population. JCO Oncol Pract 2020; 16:19-27.

9. Segi M, Fujisaku S, Kurihara M, Narai Y, Sasajima $\mathrm{K}$. The age-adjusted death rates for malignant neoplasms in some selected sites in 23 countries in 1954-1955 and their geographical correlation. Tohoku J Exp Med 1960; 72:91-103.

10. Doll R, Payne P, Waterhouse J. Cancer incidence in five continents: a technical report. New York: Springer; 1966.

11. Forman D, Bray F, Brewster H, Gombe Mablawa C, Kohler B, Piñeros M, et al. Cancer incidence in five continents. v. X. 164th Ed. Lyon: International Agency for Research on Cancer; 2014.

\section{Additional informations}

ORCID: Thayana Calixto de Carvalho (0000-00024726-0630); Anne Karin da Mota Borges (00000003-1322-3986); Rosalina Jorge Koifman (00000002-2746-7597); Ilce Ferreira da Silva (00000002-7134-3030).

12. Center MM, Jemal A, Ward E. International trends in colorectal cancer incidence rates. Cancer Epidemiol Biomarkers Prev 2009; 18:1688-94.

13. Popkin BM. The nutrition transition: an overview of world patterns of change. Nutr Rev 2004; 62 (7 Pt 2):S140-3.

14. Alexander DD, Cushing CA, Lowe KA, Sceurman B, Roberts MA. Meta-analysis of animal fat or animal protein intake and colorectal cancer. Am J Clin Nutr 2009; 89:1402-9.

15. Zhu B, Sun Y, Qi L, Zhong R, Miao X. Dietary legume consumption reduces risk of colorectal cancer: evidence from a meta-analysis of cohort studies. Sci Rep 2015; 5:8797.

16. Eaglehouse YL, Koh W-P, Wang R, Aizhen J, Yuan J-M, Butler LM. Physical activity, sedentary time, and risk of colorectal cancer: the Singapore Chinese Health Study. Eur J Cancer Prev 2017; 26:469-75.

17. Abar L, Vieira AR, Aune D, Sobiecki JG, Vingeliene S, Polemiti E, et al. Height and body fatness and colorectal cancer risk: an update of the WCRF-AICR systematic review of published prospective studies. Eur J Nutr 2018; 57:1701-20.

18. International Agency for Research on Cancer. IARC monographs on the evaluation of carcinogenic risks to humans. Lyon: International Agency for Research on Cancer; 2018.

19. Mielke GI, Hallal PC, Malta DC, Lee I-M. Time trends of physical activity and television viewing time in Brazil: 2006-2012. Int J Behav Nutr Phys Act 2014; 11:101.

20. Monteiro CA, Levy RB, Claro RM, Castro IRR, Cannon G. Increasing consumption of ultraprocessed foods and likely impact on human health: evidence from Brazil. Public Health Nutr 2011; 14:5-13. 
21. Organización de las Naciones Unidas para la Alimentación y la Agricultura; Fondo Internacional de Desarrollo Agrícola; Organización Panamericana de la Salud; Programa Mundial de Alimentos; Fondo de las Naciones Unidas para la Infancia. Panorama de la seguridad alimentaria y nutricional en América Latina y el Caribe: seguridad alimentaria y nutricional para los territorios más rezagados. Santiago de Chile: Organización de las Naciones Unidas para la Alimentación y la Agricultura/Fondo Internacional de Desarrollo Agrícola/Organización Panamericana de la Salud/Programa Mundial de Alimentos/Fondo de las Naciones Unidas para la Infancia; 2018.

22. Rubin G, Berendsen A, Crawford SM, Dommett R, Earle C, Emery J, et al. The expanding role of primary care in cancer control. Lancet Oncol 2015; 16:1231-72.

23. Espina C, Soerjomataram I, Forman D, Martín-Moreno JM. Cancer prevention policy in the EU: best practices are now well recognised; no reason for countries to lag behind. J Cancer Policy 2018; 18:40-51.

24. Ng SW, Rivera JA, Popkin BM, Colchero MA. Did high sugar-sweetened beverage purchasers respond differently to the excise tax on sugar-sweetened beverages in Mexico? Public Health Nutr 2019; 22:750-6.

25. Díaz AA, Veliz PM, Rivas-Mariño G, Mafla CV, Altamirano LMM, Jones CV. Etiquetado de alimentos en Ecuador: implementación, resultados y acciones pendientes. Rev Panam Salud Pública 2017; 41:e54.

26. Ministério da Saúde. Guia alimentar para a população brasileira. 2a Ed. Brasília: Ministério da Saúde; 2014.

27. Dirección General de la Salud, Ministerio de Salud. Guía alimentaria para la población uruguaya. Montevideo: Ministerio de Salud; 2016.

28. Brenner H, Chen C. The colorectal cancer epidemic: challenges and opportunities for primary, secondary and tertiary prevention. Br J Cancer 2018; 119:785-92.

29. World Cancer Research Fund; American Institute for Cancer Research. Diet, nutrition, physical activity and colorectal cancer. Washington DC: World Cancer Research Fund; 2017.

30. Schreuders EH, Ruco A, Rabeneck L, Schoen RE, Sung JJY, Young GP, et al. Colorectal cancer screening: a global overview of existing programmes. Gut 2015; 64:1637-49.

31. Instituto Nacional de Câncer José Alencar Gomes da Silva. ABC do câncer: abordagens básicas para o controle do câncer. Rio de Janeiro: Instituto Nacional de Câncer José Alencar Gomes da Silva; 2011.

32. Perez RO, Proscurshim I, São Julião GP, Picolo M, Gama-Rodrigues J, Habr-Gama A. Instalação e resultados preliminares de programa de rastreamento populacional de câncer colorretal em município brasileiro. Arq Bras Cir Dig 2008; 21:12-5.
33. Dutra VGP, Parreira VAG, Guimarães RM. Evolution of mortality for colorectal cancer in brazil and regions, by sex, 1996-2015. Arq Gastroenterol 2018; 55:61-5.

34. Souza DLB, Jerez-Roig J, Cabral FJ, de Lima JRF, Rutalira MK, Costa JAG. Colorectal cancer mortality in Brazil: predictions until the year 2025 and cancer control implications. Dis Colon Rectum 2014; 57:1082-9.

35. Wei EK, Giovannucci E, Wu K, Rosner B, Fuchs CS, Willett WC, et al. Comparison of risk factors for colon and rectal cancer. Int J Cancer 2004; 108:433-42.

36. Bernabe-Dones RD, Gonzalez-Pons M, VillarPrados A, Lacourt-Ventura M, Rodríguez-Arroyo $\mathrm{H}$, Fonseca-Williams S, et al. High prevalence of human papillomavirus in colorectal cancer in Hispanics: a case-control study. Gastroenterol Res Pract 2016; 2016:7896716.

37. Associação Hospitalar Moinhos de Vento. Estudo epidemiológico sobre a prevalência nacional de infecção pelo HPV - POP-Brasil. Porto Alegre: Associação Hospitalar Moinhos de Vento; 2017.

38. Scheurer ME, Tortolero-Luna G, AdlerStorthz K. Human papillomavirus infection: biology, epidemiology, and prevention. Int J Gynecol Cancer 2005; 15:727-46.

39. Instituto Nacional de Câncer José Alencar Gomes da Silva. Diretrizes brasileiras para o rastreamento do câncer do colo do útero. 2a Ed. Rio de Janeiro: Instituto Nacional de Câncer José Alencar Gomes da Silva; 2016.

40. Li M, Li JY, Zhao AL, Gu J. Colorectal cancer or colon and rectal cancer? Oncology 2007; 73:52-7.

41. US Preventive Services Task Force; BibbinsDomingo K, Grossman DC, Curry SJ, Davidson KW, Epling JW, et al. Screening for colorectal cancer: US Preventive Services Task Force Recommendation Statement. JAMA 2016; 315:2564-75.

42. American Cancer Society. Colorectal cancer facts \& figures 2020-2022. Atlanta: American Cancer Society; 2020.

43. McDevitt J, Comber H, Walsh PM. Colorectal cancer incidence and survival by sub-site and stage of diagnosis: a population-based study at the advent of national screening. Ir J Med Sci 2017; 186:113-21. 


\section{Resumo}

O estudo teve como objetivo avaliar as tendências temporais na incidência do câncer colorretal entre 1983 e 2012 na América Latina. Este é um estudo ecológico de séries temporais com uma população de indivíduos com 20 anos ou mais, diagnosticados com câncer colorretal. Foram usados os dados dos registros de câncer de base populacional de Cáli (Colômbia), Costa Rica, Goiânia (Brasil) e Quito (Equador) para estimar taxas, enquanto as estimativas das tendências temporais foram realizadas com o software Joinpoint Regression Program. O estudo mostrou um aumento na incidência do câncer colorretal em homens e mulheres em Cáli (2, $8 \%$ e 3,2\%, respectivamente), Costa Rica (3,1\% e 2,1\%, respectivamente) e Quito (2,6\% e 1,2\%, respectivamente). Em Goiânia, somente as mulheres mostraram um aumento na incidência do câncer colorretal (3,3\%). Para o câncer de cólon, houve uma tendência crescente na incidência em homens e mulheres em Cali (3,1\% e 2,9\%, respectivamente), Costa Rica (3,9\% e 2, 8\%, respectivamente) e Quito $(2,9 \%$ e $1,8 \%)$. Para o câncer retal, houve uma tendência crescente na incidência em homens e mulheres em Cali (2,5\% e 2,6\%, respectivamente), Costa Rica (2,2\% e 1\%, respectivamente) e Goiânia (5,5\% e 4,6\%, respectivamente), enquanto em Quito somente os homens mostraram tendência crescente (2,8\%). O estudo encontrou aumentos no câncer colorretal, câncer de cólon e câncer retal em quatro regiões latino-americanas. Os achados refletem mudanças no estilo de vida, como mudanças de dieta, após a abertura econômica, e variações na prevalência de fatores de risco para câncer colorretal de acordo com gênero e entre as quatro regiões estudadas. Finalmente, as diferentes estratégias adotadas pelas regiões para o diagnóstico e triagem do câncer colorretal parecem influenciar a variação observada entre os sítios anatômicos.

Neoplasias Colorretais; Incidência; Estudos de Séries Temporais; América Latina

\section{Resumen}

El objetivo fue evaluar las tendencias temporales en la incidencia del cáncer colorrectal, de 1983 a 2012, en Latinoamérica. Se trata de un estudio ecológico de series temporales, cuya población consistió en individuos con 20 años de edad, diagnosticados con cáncer colorrectal. Para las tasas de estimación se utilizaron los datos provenientes de los registros de cáncer de base poblacional en: Cali (Colombia), Costa Rica, Goiânia (Brasil), y Quito (Ecuador), mientras que las estimaciones en las tendencias temporales se obtuvieron mediante el software Joinpoint Regression Program. El estudio mostró un incremento en la incidencia de cáncer colorrectal en hombres y mujeres en Cali $(2.8 \%$ y $3.2 \%$, respectivamente), Costa Rica (3.1\% y 2.1\%, respectivamente), y Quito (2.6\% y 1.2\%, respectivamente). En Goiânia, solo las mujeres mostraron un incremento en las tasas de cáncer colorrectal (3.3\%). Para el cáncer de colon, hubo una tendencia creciente en las tasas de incidencia en hombres y mujeres en Cali (3.1\% y 2.9\%, respectivamente), Costa Rica (3.9\% y 2.8\%, respectivamente), y Quito $(2.9 \%$ y $1.8 \%)$. En el caso del cáner rectal, hubo una tendencia creciente en la incidencia en hombres y mujeres en Cali $(2.5 \%$ y $2.6 \%$, respectivamente), Costa Rica (2.2\% y 1\%, respectivamente), y Goiânia (5.5\% y 4.6\%, respectivamentre), mientras en Quito solo los hombres mostraron una tendencia creciente (2.8\%). El estudio encontró incrementos en cáncer colorrectal, cáncer de colon, y cáncer rectal en cuatro regiones de Latinoamérica. Los resultados reflejan un estilo de vida con cambios en la dieta, que siguió a la apertura económica, así como variaciones en la prevalencia de los factores de riesgo de cancer colorrectal por sexos y entre las cuatro regiones estudiadas. Finalmente, las diferentes estrategias adoptadas por las regiones para el diagnóstico del cáncer colorrectal y su pruebas de cribado parece que influencian la variación observada entre los sitios anatómicos donde surge.

Neoplasias Colorrectales; Incidencia; Estudios de Series Temporales; América Latina
Submitted on 19/Jun/2020

Final version resubmitted on 31/Jan/2021

Approved on 06/Feb/2021 